\title{
At-Risk Youth Find Work Hope in Work-Based Education
}

\author{
Connie E. Taylor, Nancy L. Hutchinson, Marcea Ingersoll, CJ Dalton \\ Jennifer Dods, Lorraine Godden, Peter Chin \\ Queen's University \\ Jennifer de Lugt \\ University of Regina
}

\begin{abstract}
The transition from school to the workplace has been identified as challenging for at-risk youth who have already disengaged from learning and feel disenfranchised in the context of school. Work-based education (WBE), including co-operative education, has been recognized in recent years as an effective strategy for enabling at-risk youth to re-engage with learning and to make more successful transitions to the workplace and to further education. Not all at-risk youth thrive in WBE, even in programs that are judged to be effective for most. What remains unclear is what changes for those previously disengaged youth, as a product of participation in WBE, that enables them to shift their perspective and reengage with learning. The purpose of this paper is to describe the experiences and changes in perspectives, in their own words, of seven previously disengaged youth while they were participating in WBE. Their teachers recommended these youth because they had made a "turnaround" since beginning WBE. The experiences and changed perspectives reported by these seven youth suggest that they found work hope through their success in WBE, and were beginning to set goals, view themselves as agents, and seek pathways to reach their goals. We discuss implications for increasing the effectiveness of WBE to re-engage even greater numbers of at-risk youth and to facilitate their transition to work by enhancing work hope.
\end{abstract}


The transition from school to the workplace has been identified as challenging for at-risk youth who have already disengaged from learning and feel disenfranchised in the context of school (Kelly, McGuinness, \& O'Connell, 2012). Work-based education (WBE), including co-operative education, has been recognized in recent years as an effective strategy for enabling at-risk youth to re-engage with learning and to make more successful transitions to the workplace and to further education (DeLuca et al., 2010; Hutchinson et al., 2011; Quintini, Martin, \& Martin, 2007). WBE refers to learning experiences for high-school students that include workplace mentoring, paid work experience, instruction in workplace competencies, and co-operative education (Smith \& Betts, 2000). Co-operative education is the most widely used form of WBE in Canada and involves youth gaining credits toward graduation by working in a placement in the community where supervision is a co-operative venture involving a supervisor from the school and a supervisor in the workplace (Ontario Ministry of Education, 2000).

Canadian researchers (e.g., O'Connor, 2003) have described at-risk youth as demonstrating disengagement from school, low achievement, and poor attendance. Engagement is usually thought to refer to participation, attachment, belonging, and investment in school-related content and activities (Fredericks, Blumenfeld, \& Paris, 2004). Disengagement is thought to be caused by factors that include students' perception that teachers are not interested in them and students' own lack of interest in what is being taught as well as their lack of optimism for the future (Yonezawa, Jones, \& Joselowsky, 2009). The result of increasing disengagement is often "dropping out," which is why these youth are described as being at risk for early school leaving. At-risk youth are defined by the Organisation for Economic Cooperation and Development (OECD) as "failing in school and unsuccessful in making the transition to work and adult life and as a consequence unable to make a full contribution to active society" (Centre for Educational Research and Innovation, 1995, p. 21). There are many examples in recent case study research to support the claim that WBE is a protective factor because it is an effective intervention for many at-risk youth (e.g., Cardon, 2000; Diamond, 2007; Munby, Zanibbi, Poth, Hutchinson, \& Chin, 2007). However, not all at-risk youth thrive in WBE, even in programs that are judged to be effective for re-engaging most participants (e.g., the cases of Jerry in Versnel, Hutchinson, Munby, \& Chin, 2008 and of Ashley in DeLuca et al., 2010). For those previously disengaged youth who do thrive in WBE, it remains unclear what changes enable them to shift their outlook and re-engage with learning.

Recently researchers have begun to explore the notion that it may be "work hope" (Juntunen \& Wettersten, 2006) that motivates these at-risk youth to look at their future differently. Work hope theory (Snyder, 2002) is discussed in some detail in the Theoretical Perspective section of this paper. Extant research on work hope and at-risk youth has employed a quantitative instrument, the Work Hope Scale (WHS; e.g., Kenny, Walsh-Blair, Blustein, Bempechat, \& Seltzer, 2010). However, qualitative studies would enable researchers to explore in more depth the aspects of WBE to which previously disengaged youth attribute these changes in their motivation and outlook. 


\section{Purpose}

The purpose of this paper is to describe youths' experiences in WBE and changes in perspectives, in their own words, of seven previously disengaged youth while they were participating in WBE. Their teachers, all working in programs recommended as exemplary work-based education, identified these youth because they had made a "turnaround" since beginning WBE. Interview questions focused on the youths' perspectives on what aspects of WBE contributed to their re-engagement, and on their contrasts of learning in WBE versus traditional school classrooms. The students' answers provided rich descriptions of how the youth experienced an iterative process between agency and pathways while identifying and setting goals for themselves.

The experiences and changed perspectives these youth reported in their individual interviews suggested to us that they had found work hope through their success in WBE, and were beginning to set goals, view themselves as agents, and seek pathways to reach their goals. This study responds to the call by Juntunen and Wettersten (2006) that researchers investigate how "hope theory may provide a useful paradigm for understanding the motivational factors associated with the work-related concerns of disenfranchised populations" (p. 104). In this paper, we situate the cases of seven students, who had been disenfranchised in school, within the context of work hope and demonstrate how co-operative education, one form of WBE, provides a context of hope for at-risk students. Using a definition of hope as "a motivational state consisting of the three components of goals, pathways, and agency" (p. 95), we underscore the effectiveness of WBE as a means for previously disengaged students to think about themselves differently and then to re-engage with learning. While much of the previous research has emphasized the features of effective WBE contexts, this paper is distinct because our approach was person-focused and the emphasis of analysis is on changes in individual students' perspectives.

\section{Theoretical Perspective}

We review literature in two fields beginning with the research on work hope followed by the research on work-based education. The role that work hope theory might play in changing the perspectives of at-risk youth is presented and the concept of work hope is connected with the population of at-risk youth engaged in WBE. The research on the structure of WBE is examined including descriptions of the programs experienced by the interviewees in this study. We contribute to the emerging understanding of how work hope can help at-risk youth to view themselves and their future differently and to reengage with the education system, enhancing their opportunities for successful transition into the world of work (e.g., Kenny et al., 2010).

\section{Work Hope}

Snyder (2002) defined hope as "the perceived capability to derive pathways to desired goals, and motivate oneself via agency thinking to use those pathways" (p. 249). Snyder (1995) conceptualized hope as a cognitive process and coping strategy. He saw humans as intrinsically goal oriented and goals as the building blocks for both learning 
and coping with daily living. He argued that both "will and way" (p. 355) are necessary, that agency and pathways are the two components that must be present to achieve goals. Snyder (2002) suggested that efforts should be made "to identify academically at risk low-hope students and target them for interventions to raise their levels of hopeful thought" (p. 259). We consider WBE to be such an intervention.

Juntunen and Wettersten (2006) saw the potential for using Snyder's hope theory as a framework with applications to career counselling and research. To this end, they developed the Work Hope Scale (WHS), an instrument used to "assess the presence of goals, strategies for obtaining those goals (pathways), and the willingness to take action to obtain those goals [agency]" (p. 96) that applies the concept of hope in the context of work. They suggested the WHS could prove to be a useful assessment tool for understanding the motivational factors of work-related concerns for disenfranchised populations: "Work hope may have particular relevance for better understanding the vocational needs of disenfranchised populations, in particular those who are denied access to privileges because of economic disadvantage" (p. 96). Youth who are at risk in school may be disenfranchised by factors like economic disadvantage and by the context of school itself.

Kenny et al. (2010) conducted a quantitative study that used Juntunen and Wettersten's WHS (2006) to measure the three components-goals, pathways, and agency-in conjunction with the Career Planning Scale (Super, Thompson, Lindeman, Jordaan, \& Myers, 1981). From their study of 201 students enrolled in WBE programs at an urban Catholic high school, Kenny et al. (2010) concluded that the construct of work hope might explain how WBE can foster academic motivation and hope for youth by helping them identify their work goals and the means to reach those goals. They suggested that "work-based learning and work hope deserve further investigation as antidotes to the academic disinterest and discouragement sometimes experienced by youth in low resource environments" (p. 210). The current qualitative study reports the first-hand experiences of at-risk youth, most from contexts of economic disadvantage, enrolled in WBE programs; and it interprets the findings through the lens of work hope theory.

After conducting a meta-analysis that examined the effect of hope-enhancement strategies in applied clinical and community settings, Weis and Speridakos (2011) reported little evidence that hope-enhancement strategies in these programs increased hopefulness or life satisfaction for participants. The authors reported, "our results call into question the effectiveness of hope enhancement strategies in applied settings" ( $p$. 12). They went on to suggest that hope may be a by-product, rather than a determinant, of goal attainment and that "hope theory can be used to select interventions that are most likely to increase agentic or pathways thinking" (p. 13). In the current study, we consider whether WBE may be an intervention that can increase agentic and pathways thinking for disengaged and at-risk youth in school settings.

Barr and Parrett (2001) reported on research that has identified the protective factors or characteristics of youth who succeed in spite of having many at-risk characteristics. One of those identified protective factors that makes youth resilient in spite of all odds is having a sense of purpose, which Barr and Parrett described as being goal-directed. These 
authors identify that "successful transitions are critical for the at-risk student" (p. 87) and that the transition from high school to the world of work can be especially perilous for atrisk youth. WBE is a frequently recommended intervention for engaging at-risk youth in school and for facilitating successful transitions into work. In the next section, we review the research on characteristics of WBE that are effective for meeting the needs of this disengaged and disenfranchised population.

\section{Work-Based Education}

WBE refers to interventions that facilitate learning by placing youth in supervised practica in workplace contexts for all or part of their educational program (Bailey, Hughes, \& Moore, 2004). These learning experiences include workplace mentoring, paid work experience, and co-operative education (Smith \& Betts, 2000). Recently, researchers have begun to consider $\mathrm{WBE}$ as a pathway to resilience for at-risk youth (Versnel, DeLuca, de Lugt, \& Hutchinson, 2011). Ungar (2009) conceptualized resilience this way:

In the context of exposure to significant adversity, resilience is both the capacity of individuals to navigate their way to the psychological, social, cultural and physical resources that sustain their well-being, and their capacity to negotiate for these resources to be provided and experienced in culturally meaningful ways. (p. 302)

This study may help us to understand the role that work hope might play in motivating youth to navigate and negotiate their way to resilience. Many approaches have been used to structure work-based education. In 2000, the most common approaches used in the United States included job site visits, job shadowing, school-sponsored enterprise, co-operative education, and apprenticeships (Stone, Kowske, \& Alfeld, 2004). Allen et al. (2004) described four kinds of programs designed to keep at-risk youth in school: reinvented high schools that created small schools within schools; institutions that minimized transition challenges by blending secondary and postsecondary education; programs that extended learning opportunities into the community to help youth gain credits; and blends of education and employment that included work experience and technical training. A Canadian study found that successful WBE programs gradually increased the complexity and accountability demanded of students in the workplace, while including students in a community of practice that combined authentic experience with mentoring (Zanibbi, Munby, Hutchinson, Versnel, \& Chin, 2006).

Students in the current study attended WBE in Ontario where the most common approach to WBE is co-operative education (co-op) and consists of both a classroom component and a placement component (Ontario Ministry of Education, 2000). In the 15to 20-hour classroom pre-placement orientation, students prepare for the workplace, learn about safety and job readiness, and develop a personalized placement learning plan (PPLP). The PPLP outlines expectations and serves as the basis for student evaluation and course credit. Co-op programs in Ontario usually: (a) provide opportunities for students to learn about occupations through community placements that match student needs and interests; (b) have distinct classroom and placement environments, with the classroom in a school and with the work placement in the community; and (c) involve a teacher as well as a workplace supervisor from a community business or organization, 
both of whom are responsible for monitoring and guiding each student (Ontario Ministry of Education, 2000).

Previous research describes the characteristics of effective WBE programs: support for individual learning, opportunities to learn through doing, career-relevant content, mentorship, and a good fit for students' needs (DeLuca et al., 2010). In a study by Hutchinson et al. (2012) teachers in exemplary Ontario WBE programs reported doing whatever it takes to keep students in school, being flexible to meet the needs of each student and finding ways to help students make connections between learning in the workplace and learning in school. According to these teachers, effective WBE creatively offers at-risk youth ways to re-engage with an alternative to the traditional school context by providing them new learning opportunities: learning that involves setting goals to acquire workplace skills and learning in alternative environments, as well as learning about problem solving and safety in the workplace. We also conducted a focus group with the WBE teachers who nominated the seven at-risk youth for the current study. We learned from these teachers about their views on what makes WBE programs effective. These teachers described how the programs "set the stage for student success" by recognizing student needs, providing a fresh start in WBE, and ensuring the students were well prepared to enter the workplace (Hutchinson et al., 2012). They also described their programs as responsive and flexible, and themselves as able to see potential in atrisk students.

In the current study, we set out to give voice to seven young people, reported to be re-engaged with learning, so they could recount their experiences and perspectives on what had changed for them. Their perspectives helped us understand what made WBE effective for them and how WBE might support other disenfranchised youth in becoming re-engaged with school and more goal oriented, and in transitioning into the work force.

\section{Method}

In the spring of 2011, we conducted focus groups with teachers working in WBE programs that had a reputation as exemplary programs. These WBE programs had either been nominated for provincial or national awards or recognized as exemplary by WBE educators working in the field. At these focus groups, teachers were asked to nominate atrisk students, those who had previously been disengaged and at risk for dropping out of school and who were currently experiencing success in WBE, to participate in individual interviews. Four teachers nominated seven Grade 11 and 12 students who agreed to participate in this investigation. These students were enrolled in WBE programs in four high schools within two district school boards in an urban area in Ontario. All but one of the programs were described by the teachers as designed for students who had experienced economic disadvantage. Ethical clearance for this research was received from the university and from the two urban school boards.

\section{Data Collection}

Each of the seven at-risk students was interviewed individually at school in a quiet place collaboratively chosen by the teacher, researcher, and student. Semi-structured interviews of 45 to 60 minutes focused on the youths' perspectives on re-engagement 
through WBE, on what the youth perceived as responsive to their needs, and on what they thought should be changed or improved in their programs. Students were asked how they came to be in the program, what they liked about it, what they had learned, and why they had chosen particular work placements. They were also asked to describe a typical day in the WBE program, to comment on how their experiences in WBE compared to their experiences at school, and to suggest who should enrol in WBE. The students' atrisk status was not the focus of our interviews, which enabled the researchers to learn about the students' needs in a way that was non-threatening. Students were informed they could terminate the interview at any time without any consequences. Data were audiorecorded and transcribed verbatim. All study participants received letters of information and all signed consent forms prior to their interviews. For those students who were younger than 18 years of age, parental consent was obtained.

\section{Data Analysis}

We used standard methods of qualitative analysis to generate themes for each participant interview followed by cross-case analyses of the seven interviews. The method of constant comparison was used to first generate codes (both etic codes arising from the work hope framework and emic codes emerging from the data) and to achieve agreement by the members of the research team on the meaning and use of these codes. After all the data had been coded, we grouped the codes into themes and subsequently grouped the themes into patterns that represented a complete picture of the data (Patton, 2002). These patterns were consistent with the three main constructs in work hope theory. Themes of meaningful learning and exploring career possibilities exemplified the way these youth thought about goals in WBE. The pathways they found in WBE to reach these goals consisted of relationships and maturing or, in their words, "growing up" through experiences in WBE. The third pattern, consistent with agency, closely connected ideas, usually spoken about together-autonomy and confidence. The research team worked collaboratively and iteratively over a number of months to examine and reexamine the data, revising and clustering the codes until a clear set of themes emerged from the analysis.

\section{Participants}

Two female and five male students were interviewed; two of them were in Grade 11 and five were in Grade 12. One of these, Eric, was enrolled in a program for students with intellectual disabilities. (Persons with intellectual disabilities are characterized by lower cognitive and adaptive development than is typical of persons of their age and tend to be identified early in life [Datta, 2014]. Although many attend neighbourhood schools, some of these students in large urban centres attend specialized secondary schools that include opportunities for WBE.) In Table 1 we describe each of the participants' past cooperative education experiences, personal context, responsibilities in the focal cooperative placement, and placement outcomes. 


\section{Table 1}

\section{Students, Placements, and Descriptive Information}

\begin{tabular}{|c|c|}
\hline Student and Placement & Descriptive Information \\
\hline $\begin{array}{l}\text { Anne (Grade } 12 \text { ) } \\
\text { Tanning salon } \\
-5 \text { hours per day }\end{array}$ & $\begin{array}{l}\text { - Two previous co-op experiences: hair salon (unsuccessful placement); } \\
\text { teacher's helper in an elementary school (successful placement). } \\
\text { - Family and teacher very supportive of co-op placement. } \\
\text { - Placement responsibilities included handling cash, scheduling clients' tanning } \\
\text { sessions, cleaning, and learning about managing a business. } \\
\text { - Outcomes included higher grades in school, sufficient credits to graduate, and } \\
\text { aspiring to become a business owner. }\end{array}$ \\
\hline $\begin{array}{l}\text { Ben (Grade 12) } \\
\text { Humane Society } \\
\text { _full days }\end{array}$ & $\begin{array}{l}\text { - Previous co-op experience: construction (unsuccessful placement). } \\
\text { - Had friends in co-op who encouraged him to try it. } \\
\text { - Responsibilities included cleaning cages, feeding and washing dogs and cats, } \\
\text { grooming, and walking the dogs. } \\
\text { - Earned the credits he needed to graduate, and acquired an interest in being } \\
\text { an animal protection services officer; learned communication and problem- } \\
\text { solving skills. }\end{array}$ \\
\hline $\begin{array}{l}\text { Cara (Grade } 11 \text { ) } \\
\text { Animal clinic } \\
-2 \text { half days per week }\end{array}$ & $\begin{array}{l}\text { - No previous co-op experience. Sister had taken co-op. } \\
\text { - Family supportive; chose placement close to home. } \\
\text { - Many responsibilities made her realize, "I was capable of a lot of things I didn't } \\
\text { know I was able to do." } \\
\text { - Hoped to do a second placement at the same clinic the following year, and } \\
\text { also to receive a summer job there. Now considering a career as a } \\
\text { veterinarian. }\end{array}$ \\
\hline $\begin{array}{l}\text { 1) } \\
\text { tractor }\end{array}$ & $\begin{array}{l}\text { - No previous co-op experience. } \\
\text { - Vice-principal recommended co-op to him as "school was not really the place } \\
\text { for me." } \\
\text { - Assisted employer in purchasing supplies and renovating buildings, including } \\
\text { installing dry-wall. } \\
\text { - Learned the importance of communication, a positive attitude, and financial } \\
\text { management; took pride in being told by employer that he was one of the best } \\
\text { co-op students he'd had. }\end{array}$ \\
\hline $\begin{array}{l}\text { Eric (Grade 12) } \\
\text { Sports retail in large } \\
\text { department store } \\
-4 \text { full days, } 5 \text { th day } \\
\text { special education classes }\end{array}$ & $\begin{array}{l}\text { - No previous co-op experience. } \\
\text { - Opportunity to work with his hands and be a "doer." } \\
\text { - Responsibilities were to serve customers, clean, and stock shelves. } \\
\text { - Enhanced valuable life skills (résumé, references, job interview), and the } \\
\text { opportunity to try out possible future work; aspires to own a business like his } \\
\text { uncle. } \\
\text { - Had been identified with intellectual disabilities (ID) and attended special } \\
\text { education classes in a school for adolescents with ID. }\end{array}$ \\
\hline $\begin{array}{l}\text { Jamie (Grade 12) } \\
\text { Physiotherapy clinic }\end{array}$ & $\begin{array}{l}\text { - Previous co-op experience: music store (unsuccessful placement). } \\
\text { - Strong connection with current placement supervisor. } \\
\text { - Responsibilities included setting up equipment and helping patients with } \\
\text { exercises. } \\
\text { - Helped him develop goals, gave him pride in his appearance; he continued to } \\
\text { dress well at school. }\end{array}$ \\
\hline $\begin{array}{l}\text { Liam (Grade 12) } \\
\text { Sports retail store }\end{array}$ & $\begin{array}{l}\text { - Previous co-op experiences: two placements at same location (both } \\
\text { successful placements). } \\
\text { - Placement matched his personal interests as an athlete. } \\
\text { - Trusted by supervisor to have a key to the shop, to open and close the store, } \\
\text { handle cash, and order supplies. } \\
\text { - Outcomes included higher marks at school, and a goal to gain full-time } \\
\text { employment at that store. }\end{array}$ \\
\hline
\end{tabular}




\section{Findings}

Rich participant data yielded five themes clustered into three patterns consistent with work hope theory: goals, pathways, and agency. Two themes in the first pattern, (a) meaningful learning, and (b) exploring career possibilities, focused on students' WBE goals. Consistent with the pathways component of work hope theory, the themes in pattern two highlighted the WBE context and emphasized (a) the importance of relationships, and (b) growing up. The construct of agency in work hope theory was highlighted in the third pattern and represented the students' sense of autonomy and confidence intertwined. These findings suggested that a work hope framework may help us to understand the powerful effects of WBE in re-engaging many at-risk youth.

\section{Goals}

Two of the study's themes were clustered under the pattern of goals that aligns with work hope theory. The first theme, meaningful learning, expressed the practical and realistic experiences that could be translated into future work skills for these seven youths. The second theme, exploring career possibilities, highlighted how the students considered and mapped out future possibilities for themselves.

Meaningful learning: "It's more like real life." WBE provided meaningful experiences that aligned with participants' interest in developing work-related skills to support immediate goals. Students expressed feeling disconnected from "real life" while in traditional classrooms and feeling a sense of inadequacy in a school system that required them to "just sit and listen." The youth we interviewed suggested that their schools were exclusionary contexts where they were considered "bad students." Liam recalled being told early on in school that he would "never make it outside of high school" while admitting to lashing out and swearing at his teachers and believing "I'm never going to get a job. I won't be able to work." Students portrayed school negatively, as a place where they did not want to be and could not achieve success. Traditional classroom education was not associated with the kind of learning that reflected participants' capabilities, interests, or goals for the future: "I have never liked school ... it just isn't for me" (Ben). Classroom learning was described as "useless," "boring," and a "waste of time." For Eric and Jamie school was just a place where "we, you know, sit down and just do paperwork" and "learn this for your test and then forget about it." Students consistently depicted WBE as their preferred learning context with "hands-on learning" and "skills that you develop along the way that you won't learn in school." Chad described how co-op is "really interesting for me because I get to use my hands constantly. I'm not just sitting there ... I'm getting the experience that I wanted.... I'm getting the experience I needed."

Although students clearly preferred the work placement component, they characterized the intensive three-week classroom component of WBE as practical and supportive: "You don't immediately start your placement, you have to ... make a résumé, you have to make a cover letter" (Anne) and "learn how to prepare for an interview" (Eric). These youth reported that WBE provided personalized opportunities to pursue their interests and develop goal-related skills. Learning "things that are more hands-on" 
ultimately provided Chad with "the most awesome feeling I've ever had" while Cara reported "it's more motivating to wake up in the morning to go to co-op than to go to school ... knowing that you're going to be doing something." The potential for meeting student interests and equipping them with practical skills made WBE consistent with their goals: doing, creating, and participating in a personally and practically meaningful context.

Exploring career possibilities: "I learned what I wanted to do in the future." Students valued the career exploration and career development opportunities provided by WBE, and used them to set goals for themselves. Through Anne's first WBE placements in hairdressing and teaching she knew that "Wow! I don't want to do this at all in my future" and stressed the advantage of eliminating these as career options and not "wasting money in school later on." By her third placement in a tanning salon, Anne believed that becoming a business owner was a vocational goal she could pursue. Cara was able in her first co-op placement to confirm her interest in working with animals: "I wasn't sure and now I'm sure." Although his first placement in landscaping was not a good fit, Chad's second placement in renovations "helped me figure out what I want to do for a living."

The real-world value of their WBE experience directly contributed to what students visualized as the next steps in achieving their immediate and future work goals. Ben felt that he would have an advantage in the workplace after high school: "You don't have to go out there looking for a job and say on your résumé that you have no employment experience.... Once you get co-op, you already have that training experience, your employer trained you for free." With their training, students expressed hope in the possibility of getting summer jobs with their co-op employers. Envisioning goals for her future education, Cara noted that her work experience would "look really good on an application to college or university." WBE re-engaged at-risk students by providing them with learning experiences that connected education to their real-life career goals and set them on pathways toward realizing new goals.

\section{Pathways}

The importance of relationships, and growing up, were two emergent themes that have been clustered under the pathways pattern of work hope theory. Learning that adult support and relationships were useful and available to the students as well as learning about their own personal capabilities both provided these students with the knowledge and pathways to move forward.

Importance of relationships: "He understands where I'm coming from." The importance students attributed to their relationships with co-op teachers, workplace supervisors, and co-workers revealed that these adults were partners on the pathway to reengagement with learning. Ben and Cara appreciated how their co-op teachers encouraged them to "take a chance" in trying co-op, and Liam explained how his teacher "was a huge support ... He basically picked me up off the ground." Jamie noted that his teacher "noticed you as a person, not [just] as a student." In crediting her teacher's support, Anne told us he was "always making sure you're in a positive environment because, obviously, if you're in a bad environment he doesn't want you there." 
Additionally, students reported that they felt respected and supported by the adults in their workplaces, describing mentors and co-workers as "really nice" people who made them feel "like family ... good friends," and "part of the team." Jamie understood the important role these partners played in his successful co-op experience: "the more they try and connect with you, the more you learn." Chad explained how he had identified with his second workplace supervisor, Norm: "I see more and more that he's just like me ... we don't like to waste time, we just get the work done. He understands where I'm coming from ... how I needed to be out of school... It's just a great connection." Initially "scared of saying the wrong thing ... having them looking down on you" in her placement, Cara revealed that "they never did that ... they always brought me up." With expectations of professionalism and maturity in the workplace, Anne's WBE co-workers treated her "like an adult instead of just like some kid." It was clear that these participants soon met these modelled work expectations, understanding that "you show up, do your work, and if you're going to be late, call" (Jamie). Ben confidently explained, if "I do my job right, I don't get any complaints." Similarly, Cara felt motivated in her placement because it was "like a job, so there's more pressure to be there and do the things that you're supposed to do." These youth, who believed they were failures in classrooms, expressed a sincere willingness to meet the expectations of the adult partners they encountered in their workplaces.

Growing up: "You learn so much about yourself." In addition to acknowledging the role that adults played as partners on this pathway, these at-risk youth expressed their own role in their personal growth. In meeting the expectations of their teachers and employers, students discovered that they were developing into mature, self-aware young adults. Jamie expressed this best when he said: "Co-op helps you realize what kind of person you are and the kind of person you want to be." In the context of his workplace Liam discussed his growing ability to regulate his behavior: "I was really angry ... but since co-op I can let that all go ... Now I'm able to think before I act. I'm able to walk away from situations and not get in confrontations with other people, especially customers." Anne explained: "You just definitely learn so much about yourself. Like I didn't know that I was so impatient.... I learned I can't be rude to a customer. Like, you just have to be more grown up ... You have to be the bigger person." All the students described becoming aware of "big changes" in their thinking and general outlook, believing that they were not just learning work-specific skills. Emphasizing his developing communication and social skills, Eric reported: "I learned more about myself-how to talk more, how to be more confident and comfortable around different people."

Before his WBE placement, Jamie explained to us, he "just didn't care at all about life in general" or about his appearance, but explained that at his workplace "you had to dress a certain way." Indicating that he had reached "that level of maturity," Jamie reported that he was "still dressing in dress shirt, dress pants, when going to school." In addition to developing people skills, Liam reported that he was "learning about life and society." In WBE, students engaged in positive relationships with adult mentors and took a path that involved them in becoming increasingly mature and responsible for their own attitudes, behaviours, and development. Once on these pathways, these at-risk students experienced personal agency with a sense of autonomy and confidence. 


\section{Agency}

The study's emergent theme of sense of autonomy and confidence clearly aligned with the pattern of agency found in work hope theory.

Sense of autonomy and confidence: "You have a lot of freedom and I was impressed with myself." These seven students often spoke of how WBE enabled them to make choices that helped them to feel confident about their abilities. Because these two ideas or themes were often spoken of together, we have reported them as one pattern that we believe reflects the agency of these previously disengaged youth.

Participants repeatedly expressed that having opportunities to make choices in their learning endeavours and to take responsibility for their actions-while gaining skills, insight, and confidence-contributed to a developing sense of pride and to their hope for future employment. Anne described being relieved to know that she could "try it and if I don't like it I can drop out," whereas Jamie explained how co-op was allowing him "to actually explore what I really want to do, not what someone else thinks I should do and that's what I really, really appreciated." It is apparent that for these young people, who were previously disenfranchised at school, being involved in work placement decisions was important. Students reported that this sense of agency and purpose contributed to their newfound willingness to take action in achieving their goals. Chad said that to succeed in WBE, a student has to "want to do it. You have to put the effort in ... the person can make the difference for themselves." He described how pursuing his personal interests has contributed to his sense of satisfaction: "It gives me a very happy feeling that I get to be creating something instead of having to just show what other people want me to do." Cara started each day of her co-op placement knowing that she had "somewhere to be, something to do, and that people are relying on me to be there."

The interviews contained many examples of how students believed that a sense of autonomy played a role in their educational re-engagement and their increasing sense of responsibility for their work. Liam described his reaction when his supervisor handed him a store key; "I was like okay, yeah, added responsibility. So, okay, I'm going to do everything proper now. It's weird how it worked, but it made me work harder." Due to his bus schedule Eric would often get to his workplace early, and he chose to start working immediately: "I decided what needed to be done because I might as well get it out of the way." Anne noted how, unlike at school, she never missed going to her placement because "I don't want to make them short staffed, like I don't want to disappoint them; you know, you think more [when you're in co-op]." In describing their co-op experiences, all of the seven students interviewed described behaviour and characteristics indicative of increased motivation and initiative.

Rich descriptions of students' opportunities for hands-on work, mentoring relationships, and meeting expectations in WBE contexts suggested that participants were developing a sense of confidence and feeling proud of their abilities and accomplishments. Liam said: "Now that I know what to do, I take a lot more initiative." Cara described how in her placement "You get to do so many things you wouldn't even think you'd be able to do ... and it actually opens your eyes to what you're capable of doing!" After feeling excluded and incapable in classroom settings, these participants now believed "okay I can do this!" and expressed hope for their futures. Liam recognized 
his own progress from being "pretty much a dropout" before his co-op placements to now excelling in his remaining credit courses: "I think it makes me feel I can accomplish a lot of things. Like if someone said I can't do it, I know that I could. I have that confidence in myself now; yeah, huge confidence." For other students considering a coop placement, Liam wanted them to know that it "completely erases what school is and makes it a lot better for you." After his WBE teacher called home to report on Chad's progress, he modestly reported that: "My mom was kind of emotional on the phone when she found out that I was one of the best co-op students that my employer [ever] had." Eric expressed his pride in doing so well in his placement that "Yeah, actually, they offered me a job there!" Common characteristics of these participants' co-op placements included opportunities for agency and for developing alternative images of themselves as successful, autonomous, confident student workers with hope for graduating and future employment.

\section{Discussion}

Recognizing their previous lack of success in school, these youth viewed their co-op programs, a form of WBE, as offering them a second chance, a means of leaving school as a graduate and of making a transition into the workplace. They recognized the role of their WBE teachers in supporting them, guiding them in preparing their résumés, exploring careers with them, and placing them in their current workplaces. They also understood that their workplace supervisors had helped them to know themselves better through what they were learning in their workplaces. In their interviews, these at-risk youth recognized and celebrated their own part in their turnaround. Thus the findings of the current study provide strong evidence for theoretically based motivational processes that link WBE and re-engagement with learning. Work hope theory can explain the turnaround often seen in at-risk youth-previously educationally disenfranchised-after they experience success in WBE (Juntunen \& Wettersten, 2006; Snyder, 2002).

WBE, an experiential out-of-school learning opportunity, provided a unique context for helping these young people to understand the value of school-based learning for their future vocational choices, provided opportunities for them to attain the credits necessary for graduation, and, most importantly, enabled them to experience themselves as competent and contributing members of society (Kenny et al., 2010). Their changed selfperceptions and motivations contributed to new behaviours, surprising even to the youth themselves. The construct of work hope has heuristic value in explaining this phenomenon (Kenny et al., 2010). Despite previous failures, poor relationships with adult educators, discouragement, disengagement, limited economic resources, and an array of obstacles, work-based learning fostered a sense of hope (Snyder, 2002).

Consistent with Snyder's (2002) suggestion, these WBE programs provided "academically at-risk low-hope students" with "interventions to raise their level of hopeful thought" (p. 259), where hope is a by-product of their WBE programs. Through their experiences in their co-op workplaces, these youth identified socially desired goals including future employment and academic achievement. They recognized their WBE educators and their workplace supervisors as providing pathways and also described their own role in developing pathways to these goals. Consistent with Snyder's emphasis on 
the need for agency, these youth described how they motivated themselves through personal agency to use these pathways and increase their confidence about reaching their goals (Juntunen \& Wettersten, 2006).

After Kenny et al. (2010) found, in a quantitative study, that work hope showed a robust relationship with achievement-related beliefs, they recommended further research on work-based learning and work hope "as antidotes to the academic disinterest and discouragement sometimes experienced by youth in low resource environments" (p. 210). The current qualitative study provides the data these researchers called for, from the perspectives of previously disengaged and discouraged youth themselves, to demonstrate the power of WBE as an intervention to promote work hope and alter motivational states of at-risk youth. Our person-focused data demonstrate that when at-risk youth feel differently about themselves and more hopeful about their future, these youth act differently in the workplace and in the school context. Further research can extend our understanding of the role work hope plays for other students across WBE programs.

\section{Implications for Research and Practice}

Much previous research (e.g., Hutchinson et al., 2010; Zanibbi et al., 2006) has focused on trying to identify the characteristics of effective WBE programs, contextual factors which are external to the youth affected by these programs. In contrast, the current study focuses on increasing our understanding of what changes in youth when they participate in these effective programs, that is, what the social cognitive mechanisms are by which the program is translated into renewed participation by at-risk youth. The current interview data suggest that these seven young people experienced the motivational processes of work hope while taking part in an intervention we describe as WBE.

Recognizing that WBE enabled these seven students to (a) set goals, (b) find pathways toward their goals, and (c) act agentically and feel confident about achieving their goals, it is important to apply these findings to understand what happens in cases where WBE does not bring about work hope in disenfranchised youth. A number of the current participants had already experienced co-op (Anne twice, Ben once, Jamie once, and Liam twice; see Table 1) and of these, three had unsuccessful co-op experiences in the past (Anne, Ben, and Jamie). This suggests that some at-risk youth may require a developmental approach to WBE in which they learn gradually through a series of opportunities.

One study to advance this agenda would involve re-examining case studies in which at-risk youth were not successful (e.g., the case of Jerry in Versnel et al., 2008) or in which they were initially less successful (e.g., the case of Ashley in DeLuca et al., 2010). The purpose would be to look specifically at the goals, pathways, and sense of agency of these youth and to consider what would have been necessary to enhance these, based on the experiences reported by these youth. Next steps to enhance our understanding of the motivational processes identified in the current study include ethnographic studies of the day-to-day experiences of at-risk youth from their first participation in WBE (similar to the case reported by Chin et al., 2004). Future research could focus on specific program features such as the timing and progression of WBE opportunities, and on relational 
features such as mentoring, workplace environment, and contextual fit. Other considerations for future research include attitudes to WBE programming from student, teacher, administrator, and parental perspectives. It would also be beneficial to provide detailed descriptions of the programs that the youth in the current study participated in. This research is underway (Hutchinson et al., 2012) and should help to identify educator perspectives and actions that characterize WBE interventions that produce work hope in at-risk youth.

Given the resounding endorsement of the current research participants for the role of WBE in their turnaround experiences, it is important for provincial policy makers, as well as school-district and school-level administrators, to increase efforts to provide alternative, work-based learning opportunities for disenfranchised students. The students described how they felt that they were not "doing anything in school"; abstract tasks were not associated with meaningful engagement, while the practical tasks of the workplace were ascribed meaning and value by these youth. Rather than continuing to try to change the students to comply with the demands of existing curricula and regular classrooms, the current data demonstrate the power of changing the educational opportunities we provide and offering more experiential learning and hands-on activities. These students, previously underachieving and in conflict with educators and administrators, thrived as a result of work-focused interactions with adults who valued their contributions to the workplace; they acquired socially appropriate, more adult outlooks and behaviours through these professional and respectful interactions. The youth described it as acting like adults when they were treated like adults.

These articulate, passionate, motivated youth make a strong case for schools' utilizing WBE as a means of motivating and re-engaging those who do not succeed in classrooms that use reading and writing as the main means of acquiring and assessing knowledge. Let us commit to giving hope to students like these seven and to enabling those least served by existing academic programs to change how they think about themselves and how they conduct themselves - so they can, in the words of Jamie, care again about school, about work, and "about life in general."

\section{References}

Allen, L., Almeida, C., \& Steinberg, A. (2004). From the prison track to the college track: Pathways to postsecondary success for out-of-school youth. Boston, MA: Jobs for the Future.

Bailey, T. R., Hughes, K. L., \& Moore, D. T. (2004). Working knowledge: Work-based learning and educational reform. New York, NY: RoutledgeFalmer.

Barr, R. D., \& Parrett, W. H. (2001). Hope fulfilled for at-risk and violent youth: K-12 programs that work (2nd ed.). Needlham Heights, MA: Allyn \& Bacon.

Cardon, P. L. (2000). At-risk students and technology education: A qualitative study. Journal of Technology Studies, 26(1), 49-57.

Centre for Educational Research and Innovation. (1995). Our children at risk. Washington, DC: Organisation for Economic Cooperation and Development (OECD).

Chin, P., Steiner Bell, K., Munby, H., \& Hutchinson, N. L. (2004). Epistemological appropriation in one high school student's learning in co-operative education. American Educational Research Journal, 41, 401-417. 
Datta, P. (2014). Students with intellectual disabilities: Insights, implications and recommendations. New York, NY: Springer.

DeLuca, C., Hutchinson, N. L., de Lugt, J., Beyer, W., Thornton, A., Versnel, J., Chin, P., \& Munby, H. (2010). Learning in the workplace: Fostering resilience in disengaged youth. Work: $A$ Journal of Prevention, Assessment \& Rehabilitation, 36, 305-319.

Diamond, M. (2007). Vocational students' engagement and career objectives: Assessment of engagement processes in new vocational students. Unpublished dissertation completed at the University of Pittsburgh, Pittsburgh, PA.

Fredericks, J. A., Blumenfeld, P., \& Paris, A. H. (2004). School engagement: Potential of the concept, state of the evidence. Review of Educational Research, 74, 59-109.

Hutchinson, N. L., Dalton, C., Dods, J., de Lugt, J., Taylor, C., DeLuca, ... Chin, P. (2010, May). A case of good fit: Individual and contextual factors in one work-based education program for at-risk youth. Paper presented at the annual meeting of the Canadian Society for the Study of Education, Montreal, QC, Canada.

Hutchinson, N. L., Versnel, J., Poth, C., Berg, D., de Lugt, J., Chin, P., Munby, H. (2011). "They want to come to school": Work-based education programs to prevent the social exclusion of vulnerable youth. Work: A Journal of Prevention, Assessment, and Rehabilitation, 39, 1-15.

Hutchinson, N. L., Versnel, J., Taylor, C., Ingersoll, M., de Lugt, J., Dalton, C., ... Chin, P. (2012, May). Using work-based education to ensure smooth transitions for at-risk youth. Paper presented at the annual meeting of the Canadian Society for the Study of Education, Waterloo, ON, Canada.

Juntunen, C. L., \& Wettersten, K. B. (2006). Work hope: Development and initial validation of a measure. Journal of Counseling Psychology, 53(1), 94-106.

Kelly, E., McGuinness, S., \& O'Connell, P. J. (2012). Transitions to long-term employment risk among young people: Evidence from Ireland. Journal of Youth Studies, 15(6), 780-801.

Kenny, M. E., Walsh-Blair, L. Y., Blustein, D. L., Bempechat, J., \& Seltzer, J. (2010). Achievement motivation among urban adolescents: Work hope, autonomy support, and achievementrelated beliefs. Journal of Vocational Behavior, 77, 205-212.

Munby, H., Zanibbi, M., Poth, C., Hutchinson, N. L., \& Chin, P. (2007). Metacognitive instruction for adolescents in the workplace: A self-questioning strategy. Education \& Training, 49(1), 8-24.

O'Connor, B. C. (2003). A successful pathway for all students: Final report of the Ontario Ministry of Education At-risk Working Group. Toronto, ON: Ministry of Education.

Ontario Ministry of Education. (2000). Co-operative education and other forms of experiential learning: Policies and procedures for Ontario secondary schools. Toronto, ON: Queen's Printer. Retrieved from http://www.edu.gov.on.ca/eng/document/curricul/secondary/co-op/cooped.pdf

Patton, M. Q. (2002). Qualitative research and evaluation methods (3rd ed.). Thousand Oaks, CA: Sage.

Quintini, G., Martin, J. P., \& Martin, S. (2007). The changing nature of the school-to-work transition process in OECD countries. Bonn, Germany: Institute for the Study of Labor (IZA).

Smith, R., \& Betts, M. (2000). Learning as partners: Realising the potential of work-based learning. Journal of Vocational Education and Training: The Vocational Aspect of Education, 52, 589604.

Snyder, C. R. (1995). Conceptualizing, measuring, and nurturing hope. Journal of Counseling \& Development, 73, 355-360.

Snyder, C. R. (2002). Hope theory: Rainbows in the mind. Psychological Inquiry, 13(4), 249-275. 
Stone, J. R., Kowske, B. J., \& Alfeld, C. (2004). Career and technical education in the late 1990s: A descriptive study. Journal of Vocational Education Research, 29, 195-223.

Super, D. E., Thompson, A. S., Lindeman, R. H., Jordaan, J. P., \& Meyers, R. A. (1981). The career development inventory. Palo Alto, CA: Consulting Psychologists Press.

Ungar, M. (2009, May). Research update-Results from Phase One. Pathways to resilience Project. Halifax, NS: Author.

Versnel, J., DeLuca, C., de Lugt, J., \& Hutchinson, N. L. (2011). Work-based education as a pathway to resilience. Journal of Educational and Vocational Research, 2(5), 143-153.

Versnel, J., Hutchinson, N. L., Munby, H., \& Chin, P. (2008). Work-based learning for adolescents with learning disabilities: Creating a context for success. Exceptionality Education Canada, $18,113-134$.

Weis, R., \& Speridakos, E. C. (2011). A meta-analysis of hope enhancement strategies in clinical and community settings. Psychology of Well-Being: Theory, Research and Practice, 1(5), 1-16.

Yonezawa, S., Jones, M., \& Joselowsky, F. (2009). Youth engagement in high schools: Developing a multidimensional, critical approach to improving engagement for all students. Journal of Educational Change, 10, 191-209.

Zanibbi, M., Munby, H., Hutchinson, N.L., Versnel, J., \& Chin, P. (2006). Exemplary practice in work-based education: A validation study. Journal of Vocational Education and Training, 58, $65-81$.

\section{Authors' Note}

Correspondence concerning this article should be addressed to: Connie E. Taylor, Queen's University, Faculty of Education, Duncan McArthur Hall, Room A106, 511 Union Street, Kingston, ON, K7M 5R7, Canada. Email: contactconnietaylor@gmail.com 